\title{
Particulate Matter and Staff Exposure in an Air-Conditioned Office in Akwa Ibom State University - Nigeria
}

\author{
Aniefiok E. Ite ${ }^{1,2, *}$, Clement O. Ogunkunle ${ }^{3}$, Clement O. Obadimu ${ }^{1}$, Ekpedeme R. Asuaiko ${ }^{4}$, Udo J. Ibok ${ }^{1}$ \\ ${ }^{1}$ Department of Chemistry, Akwa Ibom State University, P. M. B. 1017, Uyo, Akwa Ibom State, Nigeria \\ ${ }^{2}$ Research and Development Unit, Akwa Ibom State University, P. M. B. 1017, Uyo, Akwa Ibom State, Nigeria \\ ${ }^{3}$ Environmental Biology Unit, Department of Plant Biology, University of Ilorin, Nigeria \\ ${ }^{4}$ Department of Geology, Akwa Ibom State University, P. M. B. 1017, Uyo, Akwa Ibom State, Nigeria \\ *Corresponding author: aniefiokite@yahoo.co.uk
}

\begin{abstract}
Indoor air quality parameters were investigated in an occupied air-conditioned office and unoccupied air-conditioned office located in the Faculty of Natural and Applied Sciences Complex in Akwa Ibom State University - Nigeria, during the rainy (June - July) and dry (November - December) seasons of 2016. Particulate matter $\left(\mathrm{PM}_{1}, \mathrm{PM}_{2}, \mathrm{PM}_{5}, \mathrm{PM}_{10}\right)$, temperature, relative humidity, carbon monoxide (CO) and carbon dioxide $\left(\mathrm{CO}_{2}\right)$ levels were simultaneously measured in fourteen (14) sampling days using Fluke 985 Particle Counter and Fluke 975 AirMeter. The concentrations of particulate matter in the occupied air-conditioned office during the rainy season ranged from $5152-5984 \mu \mathrm{g} / \mathrm{m}^{3}$ for $\mathrm{PM}_{1} ; 2744-3015 \mu \mathrm{g} / \mathrm{m}^{3}$ for $\mathrm{PM}_{2} ; 137-149 \mu \mathrm{g} / \mathrm{m}^{3}$ for $\mathrm{PM}_{5}$ and $36-50 \mu \mathrm{g} / \mathrm{m}^{3}$ for $\mathrm{PM}_{10}$ and in the unoccupied air-conditioned office, the concentrations of particulate matter ranged from $1898-2556 \mu \mathrm{g} / \mathrm{m}^{3}$ for $\mathrm{PM}_{1} ; 987-1311 \mu \mathrm{g} / \mathrm{m}^{3}$ for $\mathrm{PM}_{2} ; 38-59 \mu \mathrm{g} / \mathrm{m}^{3}$ for $\mathrm{PM}_{5}$ and $15-24 \mu \mathrm{g} / \mathrm{m}^{3}$ for $\mathrm{PM}_{10}$. During the dry season, the concentrations of particulate matter in the occupied air-conditioned office ranged from $5852-6510 \mu \mathrm{g} / \mathrm{m}^{3}$ for $\mathrm{PM}_{1} ; 4490-4992 \mu \mathrm{g} / \mathrm{m}^{3}$ for $\mathrm{PM}_{2} ; 335-362 \mu \mathrm{g} / \mathrm{m}^{3}$ for $\mathrm{PM}_{5}$ and $59-69 \mu \mathrm{g} / \mathrm{m}^{3}$ for $\mathrm{PM}_{10}$ and in the unoccupied air-conditioned office, the concentrations of particulate matter ranged from $2598-3112 \mu \mathrm{g} / \mathrm{m}^{3}$ for $\mathrm{PM}_{1} ; 1168-1694 \mu \mathrm{g} / \mathrm{m}^{3}$ for $\mathrm{PM}_{2} ; 153-257 \mu \mathrm{g} / \mathrm{m}^{3}$ for $\mathrm{PM}_{5}$ and $29-42 \mu \mathrm{g} / \mathrm{m}^{3}$ for $\mathrm{PM}_{10}$. This study has revealed that the particulate matter $\left(\mathrm{PM}_{1}, \mathrm{PM}_{2}, \mathrm{PM}_{5}, \mathrm{PM}_{10}\right)$ concentrations in an occupied air-conditioned office were significantly $(P<0.001)$ higher than those obtained in unoccupied air-conditioned office during both rainy and dry seasons. However, the concentrations of $\mathrm{PM}_{10}$ obtained in the present study were found to be much lower than the ambient maximum contaminant level for airborne $\mathrm{PM}_{10}$ standard promulgated by the United States Environmental Protection Agency (USEPA) $\left(150 \mu \mathrm{g} / \mathrm{m}^{3}\right.$ daily average and $50 \mu \mathrm{g} / \mathrm{m}^{3}$ annual average) and World Health Organization (WHO) $\mathrm{PM}_{10}$ guidelines values $\left(50 \mu \mathrm{g} / \mathrm{m}^{3}\right.$ daily average and $20 \mu \mathrm{g} / \mathrm{m}^{3}$ annual average). Although there were no significant relationships among $\mathrm{PM}_{1}, \mathrm{PM}_{2}, \mathrm{PM}_{5}$, and $\mathrm{PM}_{10}$ in occupied air-conditioned office, correlation analysis indicated that $\mathrm{PM}_{1}, \mathrm{PM}_{2}$ and $\mathrm{PM}_{5}$ were significantly correlated at $P<0.01$ in unoccupied air-conditioned office and correlation coefficients were different. Apart from suspended atmospheric dust and settling dust, human activities in the occupied air-conditioned office significantly influenced the particulate matter concentrations obtained compared to those obtained in unoccupied air-conditioned office in both rainy and dry seasons. Although the concentrations of $\mathrm{CO}$ and $\mathrm{CO}_{2}$ were below detection limit (BDL), they indicated adequate air exchange at the time of the assessment in the air-conditioned office during the sampling period. The results obtained have revealed important contributions towards the understanding of particulate matter distribution patterns and provided baseline data that can be used for potential identification of human health risks associated with airborne particulate matter in air-conditioned offices in Akwa Ibom State University - Nigeria.
\end{abstract}

Keywords: indoor air quality, particulate matter, air-conditioned office, staff exposure, Akwa Ibom State University

Cite This Article: Aniefiok E. Ite, Clement O. Ogunkunle, Clement O. Obadimu, Ekpedeme R. Asuaiko, and Udo J. Ibok, "Particulate Matter and Staff Exposure in an Air-Conditioned Office in Akwa Ibom State University - Nigeria." Journal of Atmospheric Pollution, vol. 5, no. 1 (2017): 24-32. doi: 10.12691/jap-5-1-4.

\section{Introduction}

Particulate matter (PM), the suspended material of the atmosphere, is a complex mixture of extremely small particles (solids) and liquid droplets of primary and secondary origin that contain a wide range of inorganic and organic components. PM can be emitted from both natural sources such as volcanic eruption, sea spray aerosols and wind-blown desert dust as well as anthropogenic sources such as agricultural operations, gas 
flaring and venting, urbanization, forest fires, industrial processes, power generation, entrainment of road dust into the air and all means of transportation that use fossil fuels. Over the years, airborne PM or particle pollution has been one of the most important parameters in air pollution studies due to its adverse health and environmental impacts. It is known that the spatial and temporal distribution of PM is variable and is strongly influenced by both climatic and meteorological conditions [1,2]. According to Hinds [3], PM can be categorized into three size ranges as ultrafine $(d \mathrm{p}<0.1 \mu \mathrm{m}$, UFP), fine $(0.1<d \mathrm{p}$ $<2.5 \mu \mathrm{m})$, and coarse $(d \mathrm{p}>2.5 \mu \mathrm{m})$ particles. It is known that the size distribution of PM in an ambient air is trimodal according to the aerodynamic diameter [4]. Although PM is found in both outdoor and indoor environments, coarse and fine particles sum up to particles with an aerodynamic diameter less than $10 \mu \mathrm{m}\left(\mathrm{PM}_{10}\right)$. PM can be suspended over long period of time and can travel over long distances in the atmosphere, and as such significantly affect local and/or regional air quality, human health and climate change.

Air quality policy and emissions regulations are typically based on the mass of size fractions of $\mathrm{PM}_{10}$ (inhalable fraction which may reach the upper part of the airways and lung) and/or $\mathrm{PM}_{2.5}$ (more able to deeply penetrate the lungs and alveoli) [1]. Over the years, several epidemiological studies have confirmed that PM, especially the respirable fraction of $\mathrm{PM}$, the $\mathrm{PM}_{2.5}$ (for particles $<2.5 \mu \mathrm{m}$ diameter), has adverse effects on human health [5-19]. Some of the human health effects of inhalable PM include respiratory and cardiovascular morbidity, such as aggravation of asthma and respiratory symptoms; chronic lung diseases; premature mortality, decreased lung function, mortality from cardiovascular and respiratory diseases, and from lung cancer. According to Strak et al. [19], increases in airborne PM have been associated with an elevated risk of stroke, myocardial ischaemia and coronary heart disease as well as activation of blood coagulation. It is known that a greater number of both academic and non-academic staff working in the higher and tertiary institutions tend to spend more time indoors than outdoors. Recently, indoor air quality in private homes and in public places has therefore been of interest to the various researchers and the general public in developing countries around the world. Good indoor air quality in classrooms provides healthy learning environment to children, promotes learning ability and also helps to make teachers as well as staff to be more productive [20]. Some of the main factors affecting indoor environment include temperature, humidity, air exchange rate, air movement, ventilation, particle pollutants, biological pollutants, and gaseous pollutants [21]. Although the wide use of air conditioning helps to improve thermal comfort, there are several human health problems associated with poor Indoor Air Quality (IAQ) around the world [22].

The exposure to ambient PM is a major threat to public health and poor indoor air quality can cause a wide range of health-related symptoms that may lead to a significant reduction in human productivity as well as increased mortality. Although PM-related air pollution affects cardiorespiratory health, it is unclear which particle size fractions and sources of particles are responsible for the human health effects $[13,15]$. However, human health effects associated with both indoor and outdoor environmental air pollutants have been of great concern due to the high exposure risk even at relatively low concentrations of the air pollutants [10]. It is known that PM may be generated within the built environment or may be transported into and/or from outside via various mechanisms. Although few studies have been performed regarding indoor air quality in offices in developed countries around the world $[23,24,25,26]$, the exposure of office workers to health relevant air pollutants have not been fully characterized in Nigeria. Therefore, the present study investigates PM and Staff Exposure in an occupied air-conditioned office and unoccupied air-conditioned office located in the Faculty of Natural and Applied Sciences Complex in Akwa Ibom State University Main Campus during the rainy (June - July) and dry (November - December) seasons of 2016.

\section{Materials and Methods}

\subsection{Sampling Location and Air Conditioning}

This study was carried out in an occupied airconditioned office and unoccupied air-conditioned office within the Faculty of Natural and Applied Sciences Complex, Akwa Ibom State University Main Campus located at Ikot Akpaden, Mkpat Enin Local Government Area of Akwa Ibom State, Nigeria (Figure 1). Ikot Akpaden is a growing town located within the low lands of southeast Nigeria. It sits at a latitude of $4^{\circ} 37^{\prime} 38.2^{\prime \prime}$ $\left(4.6273^{\circ}\right)$ north and longitude of $7^{\circ} 46^{\prime} 22.8^{\prime \prime}\left(7.773^{\circ}\right)$ east with an average elevation of 18 metres (59 feet). Prior to this study, split air conditioners (AC) in the offices were installed on the wall and the outdoor air intake of the air conditioner was 133 litres per second when the AC was turned on. The mixture of outdoor and return air was filtered (45 mm thick filter) before passing through the cooling coil. The windows in the offices were kept closed during the assessment period and only ceiling fans and the supply-air fan of the AC unit served as exhaust ventilation as well as exhaust air system. The characteristics of the office selected for the study are presented in Table 1.

Table 1. Overview of office characteristics

\begin{tabular}{|c|c|}
\hline Number of occupant & 1 \\
\hline Volume $\left(\mathrm{m}^{3}\right)$ & 1000 \\
\hline Floor area $\left(\mathrm{m}^{2}\right)$ & 100 \\
\hline Number of windows & 2 \\
\hline Number of fans & 1 \\
\hline Cleaning frequency & Once daily \\
\hline
\end{tabular}

\subsection{Monitoring Protocol}

Measurements were carried out for 14 days in two campaigns performed in June - July (rainy season) and November - December (dry season) of 2016. The indoor $\mathrm{PM}_{1}, \mathrm{PM}_{2}, \mathrm{PM}_{5}$, and $\mathrm{PM}_{10}$ mass concentrations were monitored simultaneously using Fluke 985 Particle Counter (Fluke Corporation, United Kingdom). The Fluke 
985 Particle Counter (with six channels and particle size range of $0.3-10.0 \mu \mathrm{m}$ ) is ideal for troubleshooting and monitoring of indoor air quality issues and verifying heating, ventilation and air conditioning (HVAC) filter performance. In addition, the Fluke 975 AirMeter was used to simultaneously measure, logs, and display temperature, relative humidity, $\mathrm{CO}_{2}$, and $\mathrm{CO}$ concentrations (Fluke Corporation, United Kingdom). The Fluke 975 AirMeter automatically compensates for barometric pressure changes and has an extensive discrete or continuous data logging capacity.

\subsection{Statistical Analysis}

Descriptive statistics were used to characterize indoor particle concentrations and the air quality parameters were grouped according to the occupation status of the office and rainy or dry seasons in which they were obtained. Statistical analyses were conducted to determine and evaluate the impact of relevant parameters on the particle concentrations and staff exposure in the the occupied air-conditioned and unoccupied air-conditioned offices. A value of $P<0.05$ was considered statistically significant. All data analyses were carried out using statistical software - SigmaStat ${ }^{\circledR}$, Version 3.5 (Systat Software Inc., USA). The airborne PM distribution profiles are presented using graphing software package - SigmaPlot ${ }^{\circledR}$, Version 12.5 (Systat Software Inc., USA).

\section{Results and Discussion}

Among the indoor air pollutants monitored, PM concentrations were found to be significant in the occupied air-conditioned office. The $\mathrm{CO}$ and $\mathrm{CO}_{2}$ levels were below detection limit (BDL) inside both the occupied air-conditioned office and unoccupied air-conditioned office during the monitoring period. The BDL of $\mathrm{CO}$ and $\mathrm{CO}_{2}$ show adequate ventilation in the air-conditioned office during the assessment period. Table 2 presents the descriptive statistics of daily average IAQ parameters during the sampling period. The data were grouped into two periods: the rainy season (June - July) and dry season (November - December) of 2016. The seasonal variations of PM $\left(\mathrm{PM}_{1}, \mathrm{PM}_{2}, \mathrm{PM}_{5}, \mathrm{PM}_{10}\right)$ concentrations in both an occupied air-conditioned office and an unoccupied airconditioned office during rainy and dry seasons are graphically presented in Figure 2 - Figure 5.

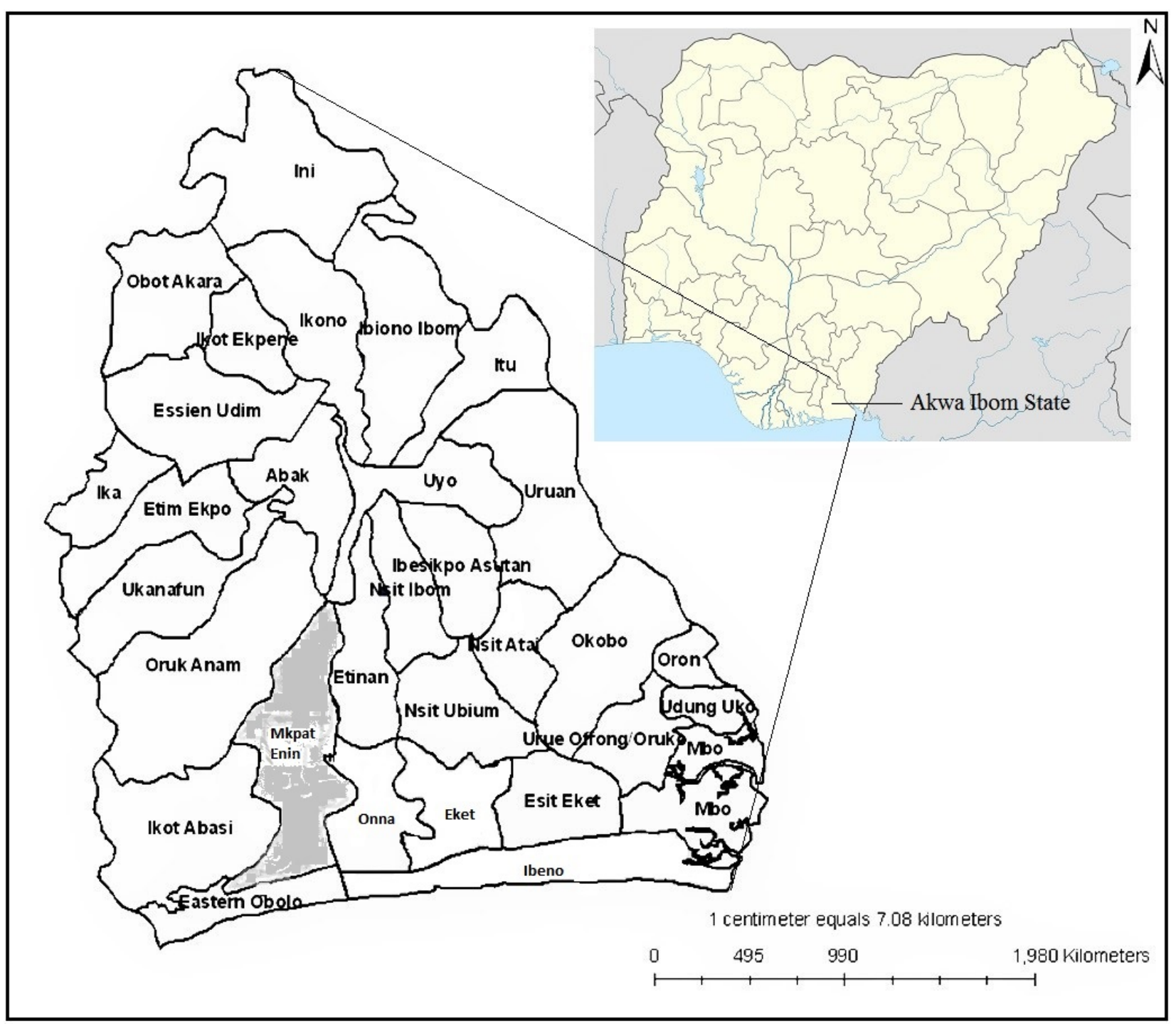

Figure 1. Map of Nigeria Showing the Location of Akwa Ibom State (Study Area: Akwa Ibom State University Main Campus Located in Ikot Akpaden, Mkpat Enin Local Government Areas) 

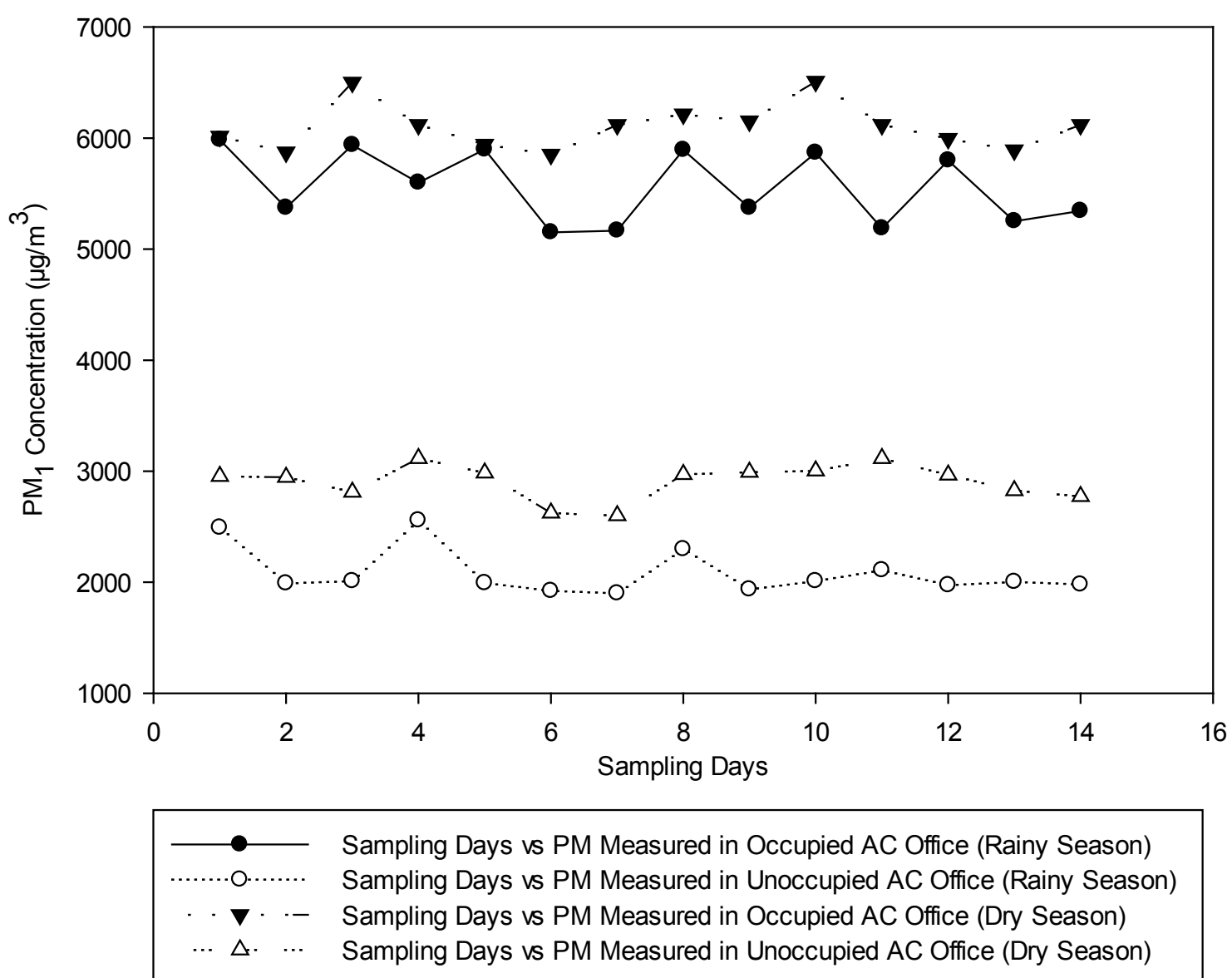

Figure 2. Seasonal Variations of $\mathrm{PM}_{1}$ Concentrations in an Air-Conditioned Office during Rainy and Dry Seasons
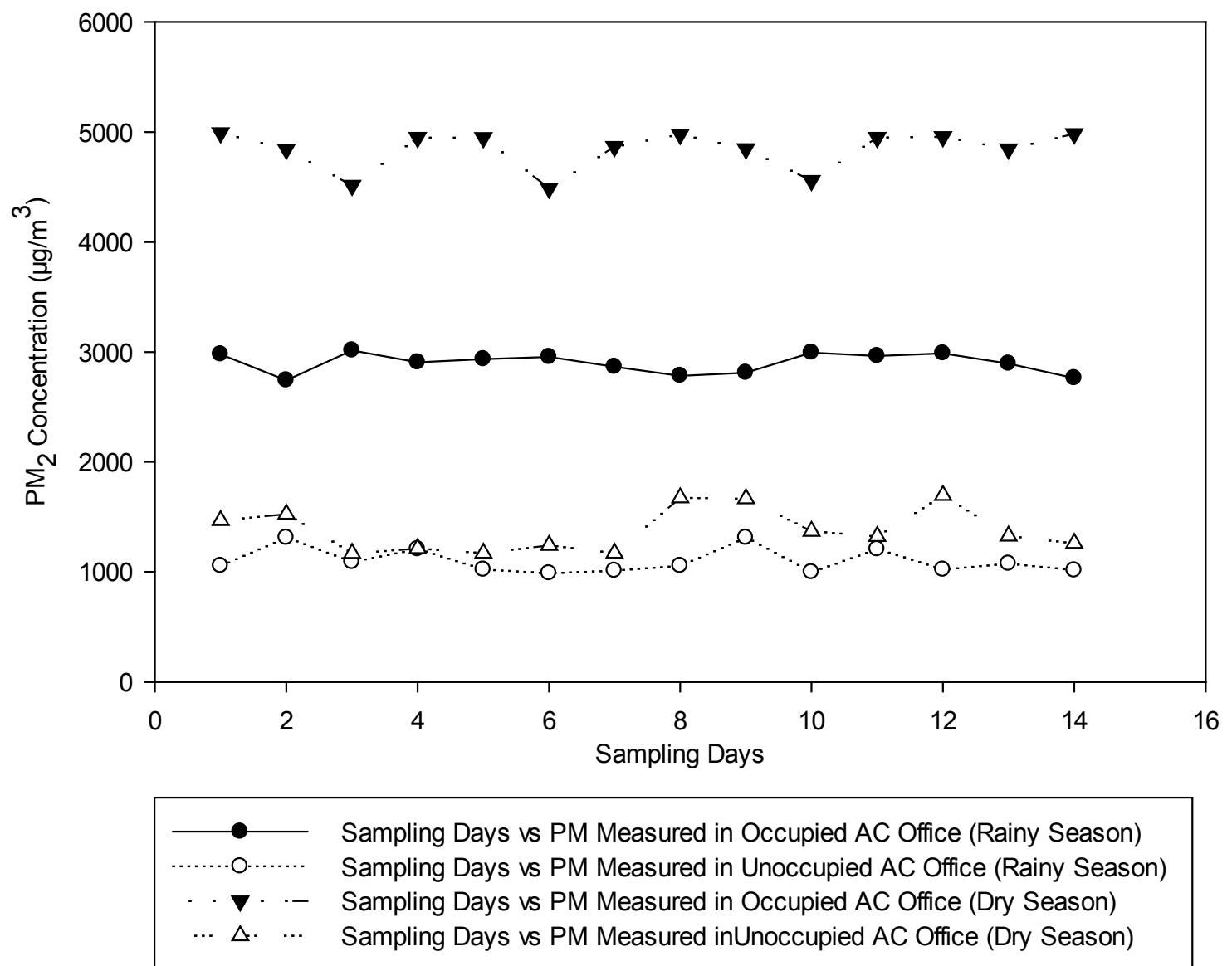

Figure 3. Seasonal Variations of $\mathrm{PM}_{2}$ Concentrations in an Air-Conditioned Office during Rainy and Dry Seasons 

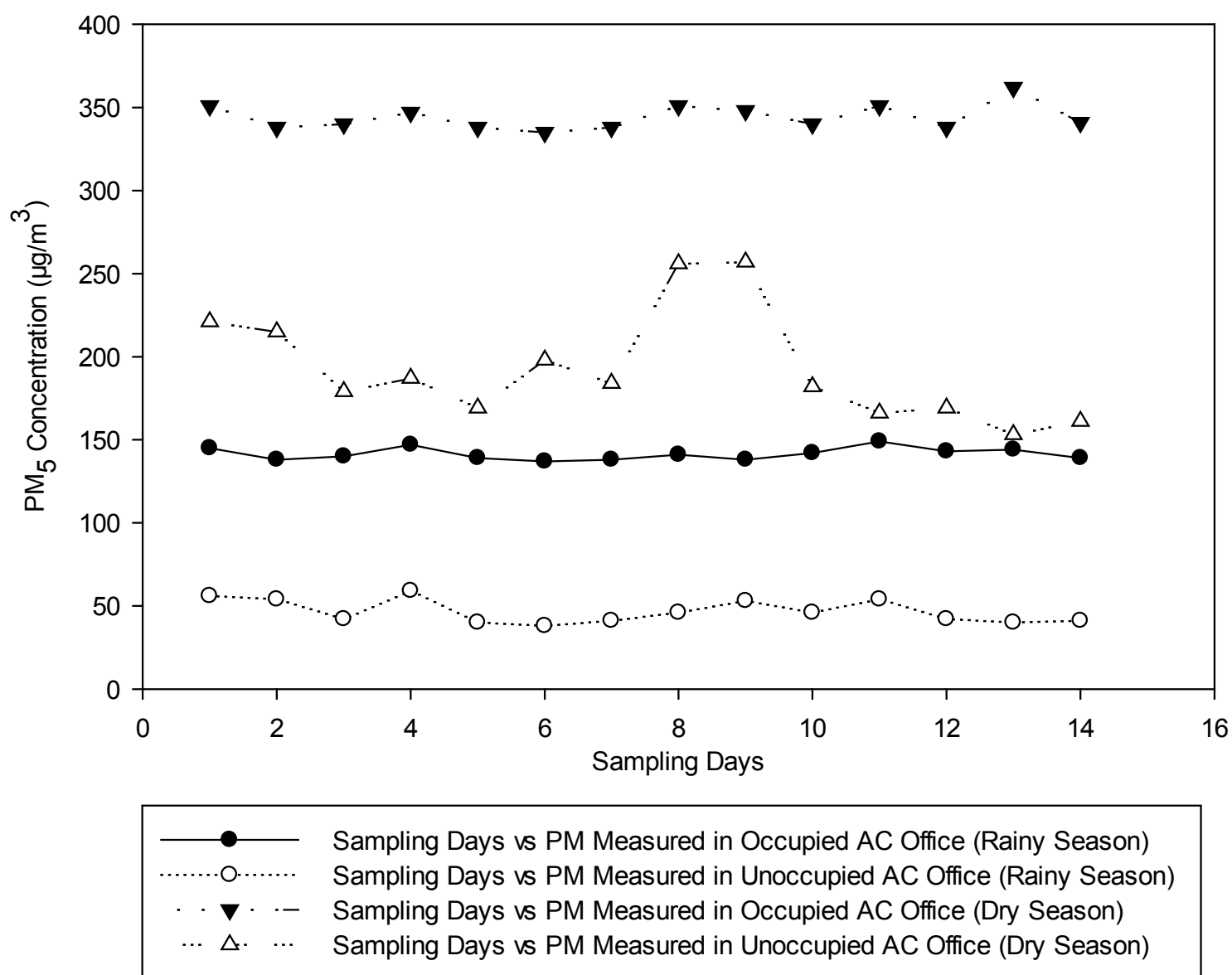

Figure 4. Seasonal Variations of $\mathrm{PM}_{5}$ Concentrations in an Air-Conditioned Office during Rainy and Dry Seasons
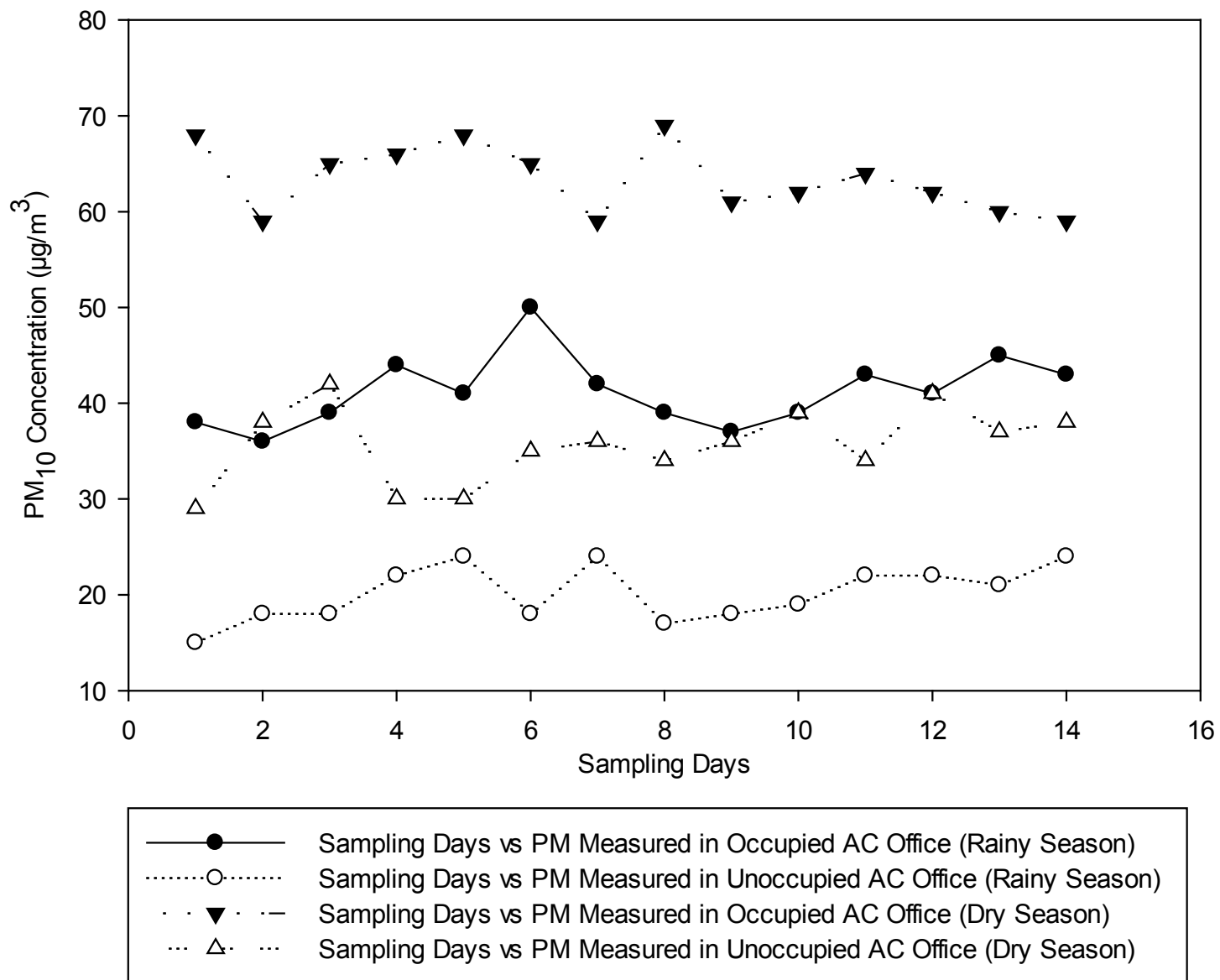

Figure 5. Seasonal Variations of $\mathrm{PM}_{10}$ Concentrations in an Air-Conditioned Office during Rainy and Dry Seasons 
Table 2. Descriptive statistics of daily average Indoor Air Quality (IAQ) parameters

\begin{tabular}{|c|c|c|c|c|c|c|c|c|c|c|}
\hline \multirow[b]{2}{*}{ Season } & \multirow[t]{2}{*}{ Period } & & \multicolumn{5}{|l|}{ Pollutants } & \multicolumn{3}{|c|}{ Comfort parameters } \\
\hline & & & $\begin{array}{c}\mathrm{PM}_{1} \\
\left(\mu \mathrm{g} / \mathrm{m}^{3}\right)\end{array}$ & $\begin{array}{c}\mathrm{PM}_{2} \\
\left(\mu \mathrm{g} / \mathrm{m}^{3}\right) \\
\end{array}$ & $\begin{array}{c}\mathrm{PM}_{5} \\
\left(\mu \mathrm{g} / \mathrm{m}^{3}\right) \\
\end{array}$ & $\begin{array}{c}\mathrm{PM}_{10} \\
\left(\mu \mathrm{g} / \mathrm{m}^{3}\right) \\
\end{array}$ & $\begin{array}{c}\mathrm{CO} \\
(\mathrm{ppm}) \\
\end{array}$ & $\mathrm{CO}_{2}(\mathrm{ppm})$ & $\mathrm{T}\left({ }^{\circ} \mathrm{C}\right)$ & RH (\%) \\
\hline \multirow{5}{*}{ Rainy } & \multirow{5}{*}{$\begin{array}{c}\text { Occupied } \\
\text { Air-Conditioned } \\
\text { Office }\end{array}$} & Mean & 5559.00 & 2900.64 & 141.43 & 41.21 & BDL & BDL & 25.16 & 79.51 \\
\hline & & Min & 5152.00 & 2744.00 & 137.00 & 36.00 & $\mathrm{BDL}$ & BDL & 24.60 & 78.60 \\
\hline & & Max & 5984.00 & 3015.00 & 149.00 & 50.00 & $\mathrm{BDL}$ & BDL & 25.70 & 79.90 \\
\hline & & Median & 5486.00 & 2921.50 & 140.50 & 41.00 & $\mathrm{BDL}$ & BDL & 25.20 & 79.90 \\
\hline & & SD & 325.08 & 92.16 & 3.72 & 3.68 & BDL & BDL & 0.38 & 0.60 \\
\hline \multirow{15}{*}{ Dry } & \multirow{5}{*}{$\begin{array}{c}\text { Unoccupied } \\
\text { Air-Conditioned } \\
\text { Office }\end{array}$} & Mean & 2082.0 & 1096.86 & 46.57 & 20.14 & BDL & BDL & 24.89 & 79.51 \\
\hline & & Min & 1898.00 & 987.00 & 38.00 & 15.00 & $\mathrm{BDL}$ & BDL & 23.70 & 78.60 \\
\hline & & Max & 2556.00 & 1311.00 & 59.00 & 24.00 & BDL & BDL & 25.60 & 79.90 \\
\hline & & Median & 1996.00 & 1054.00 & 44.00 & 20.00 & $\mathrm{BDL}$ & BDL & 25.15 & 79.90 \\
\hline & & SD & 210.78 & 113.61 & 7.12 & 2.93 & $\mathrm{BDL}$ & BDL & 0.67 & 0.60 \\
\hline & \multirow{5}{*}{$\begin{array}{c}\text { Occupied } \\
\text { Air-Conditioned } \\
\text { Office }\end{array}$} & Mean & 6101.93 & 4838.00 & 344.14 & 63.36 & BDL & BDL & 24.85 & 78.41 \\
\hline & & Min & 5852.00 & 4490.00 & 335.00 & 59.00 & BDL & BDL & 24.20 & 76.50 \\
\hline & & Max & 6510.00 & 4992.00 & 362.00 & 69.00 & BDL & BDL & 25.40 & 79.90 \\
\hline & & Median & 6120.00 & 4908.00 & 340.50 & 63.00 & BDL & BDL & 25.00 & 78.600 \\
\hline & & SD & 204.92 & 180.03 & 7.66 & 3.57 & BDL & BDL & 0.38 & 1.04 \\
\hline & \multirow{5}{*}{$\begin{array}{c}\text { Unoccupied } \\
\text { Air-Conditioned } \\
\text { Office }\end{array}$} & Mean & 2903.21 & 1375.29 & 192.64 & 35.64 & BDL & BDL & 24.86 & 76.93 \\
\hline & & Min & 2598.00 & 1168.00 & 153.00 & 29.00 & $\mathrm{BDL}$ & BDL & 23.70 & 74.60 \\
\hline & & Max & 3112.00 & 1694.00 & 257.00 & 42.00 & BDL & BDL & 25.60 & 78.40 \\
\hline & & Median & 2957.50 & 1323.50 & 183.00 & 36.00 & BDL & BDL & 24.90 & 77.00 \\
\hline & & SD & 158.72 & 195.52 & 33.16 & 3.99 & BDL & BDL & 0.64 & 1.32 \\
\hline
\end{tabular}

NOTES: $\mathrm{CO}=$ Carbon monoxide, $\mathrm{CO}_{2}=$ Carbon dioxide, $\mathrm{T}=$ Temperature, $\mathrm{RH}=$ Relative humidity, $\mathrm{BDL}=\mathrm{Below}$ Detection Limit.

The concentrations of particulate matter obtained in the occupied air-conditioned office during the rainy season ranged from $5152-5984 \mu \mathrm{g} / \mathrm{m}^{3}$ for $\mathrm{PM}_{1} ; 2744-3015$ $\mu \mathrm{g} / \mathrm{m}^{3}$ for $\mathrm{PM}_{2} ; 137-149 \mu \mathrm{g} / \mathrm{m}^{3}$ for $\mathrm{PM}_{5}$ and $36-50$ $\mu \mathrm{g} / \mathrm{m}^{3}$ for $\mathrm{PM}_{10}$ and for an unoccupied air-conditioned office, the concentrations of particulate matter ranged from $1898-2556 \mu \mathrm{g} / \mathrm{m}^{3}$ for $\mathrm{PM}_{1} ; 987-1311 \mu \mathrm{g} / \mathrm{m}^{3}$ for $\mathrm{PM}_{2} ; 38-59 \mu \mathrm{g} / \mathrm{m}^{3}$ for $\mathrm{PM}_{5}$ and $15-24 \mu \mathrm{g} / \mathrm{m}^{3}$ for $\mathrm{PM}_{10}$. During the dry season, the concentrations of particulate matter obtained in the occupied air-conditioned office ranged from $5852-6510 \mu \mathrm{g} / \mathrm{m}^{3}$ for $\mathrm{PM}_{1} ; 4490-4992$ $\mu \mathrm{g} / \mathrm{m}^{3}$ for $\mathrm{PM}_{2} ; 335-362 \mu \mathrm{g} / \mathrm{m}^{3}$ for $\mathrm{PM}_{5}$ and $59-69$ $\mu \mathrm{g} / \mathrm{m}^{3}$ for $\mathrm{PM}_{10}$ and for an unoccupied air-conditioned office, the concentrations of particulate matter ranged from $2598-3112 \mu \mathrm{g} / \mathrm{m}^{3}$ for $\mathrm{PM}_{1} ; 1168-1694 \mu \mathrm{g} / \mathrm{m}^{3}$ for $\mathrm{PM}_{2} ; 153-257 \mu \mathrm{g} / \mathrm{m}^{3}$ for $\mathrm{PM}_{5}$ and $29-42 \mu \mathrm{g} / \mathrm{m}^{3}$ for $\mathrm{PM}_{10}$. The results obtained from this study revealed that the particulate matter $\left(\mathrm{PM}_{1}, \mathrm{PM}_{2}, \mathrm{PM}_{5}, \mathrm{PM}_{10}\right)$ concentrations obtained in an occupied air-conditioned office were significantly $(P<0.001)$ higher than those obtained in unoccupied air-conditioned office in both rainy and dry seasons. It is known that human activities may act as an important indoor source for PM in classrooms considering the fact that the occupant density in the schools was several times higher than those obtained in the other buildings $[27,28,29]$. In the present study, it was found that indoor $\mathrm{PM}_{10}$ concentrations varied significantly with occupant's activities and higher $\mathrm{PM}_{10}$ concentrations obtained in an occupied air-conditioned office were attributed to the presence of people with resuspension activities being the most important source for particle sizes larger than $1 \mu \mathrm{m}$ [23].
Apart from resuspension of previously deposited $\mathrm{PM}_{10}$ particle in the occupied air-conditioned office, their delayed deposition/settlement as a result of induced turbulence created by occupant's movements might have contributed to higher indoor $\mathrm{PM}_{10}$ concentrations obtained [30]. According to Thatcher and Layton [31], even low activity can have a significant impact on the concentration of air borne particles with diameters greater than $5 \mu \mathrm{m}$. Apart from particles with diameter $<5 \mu \mathrm{m}$ which are not readily re-suspended, it has been revealed that just walking into and out of the room can increase the mass of coarse particles by almost $100 \%$ [30,31]. Over the years, several studies have been conducted with the aim of understanding indoor air quality of school environments across the world [27,28,29,30,32-38]. In a study, Tippayawong et al. [38] found that the highest concentrations were obtained for particles in the $0.3-0.5$ $\mu \mathrm{m}$ size range with an average value of $180 \mathrm{~cm}^{-3}$ while the lowest concentrations were obtained in the $2.5-5 \mu \mathrm{m}$ size range with an average of $0.05 \mathrm{~cm}^{-3}$. In a related study, Parker et al. [39] reported that while the smallest particle $(0.3-0.4 \mu \mathrm{m})$ concentrations remained relatively constant over a day between about 4 and $8 \mathrm{~cm}^{-3}$, coarse particles $(7.5-10 \mu \mathrm{m})$ concentrations rose with occupancy from zero to about $0.025 \mathrm{~cm}^{-3}$ during typical days. The building studied by Tippayawong et al. [38] was naturally ventilated and had higher concentrations than those obtained in this study, while Parker et al. [39] studied a mechanically ventilated building which had lower concentrations. In the present study, the investigation of IAQ was carried out in an air-conditioned office and the windows were kept closed at all times. However, the 
entrance door was open for the occupant which may have served as a route for PM transport from outside.

In this study, the concentrations of $\mathrm{PM}_{10}$ obtained in an air-conditioned office during the sampling period were found to be much lower than the ambient maximum contaminant level for airborne $\mathrm{PM}_{10}$ standard promulgated by the United States Environmental Protection Agency (USEPA) $\left(150 \mu \mathrm{g} / \mathrm{m}^{3}\right.$ daily average and $50 \mu \mathrm{g} / \mathrm{m}^{3}$ annual average) and World Health Organization (WHO) $\mathrm{PM}_{10}$ guidelines values $\left(50 \mu \mathrm{g} / \mathrm{m}^{3}\right.$ daily average and $20 \mu \mathrm{g} / \mathrm{m}^{3}$ annual average). The WHO suggested Global Air-Quality Guideline values are as follows $10 \mu \mathrm{g} / \mathrm{m}^{3}$ annual mean, $25 \mu \mathrm{g} / \mathrm{m}^{3}$ 24-hour mean for $\mathrm{PM}_{2.5}$ and $20 \mu \mathrm{g} / \mathrm{m}^{3}$ annual mean, $50 \mu \mathrm{g} / \mathrm{m}^{3}$ 24-hour mean for $\mathrm{PM}_{10}$ [40]. Apart from the suspended atmospheric dust and settling dust, activities carried out in the occupied air-conditioned office significantly influenced the particulate matter concentrations obtained compared to that in the unoccupied air-conditioned office. It has been observed that the IAQ of the school building could be influenced by outdoor pollutant sources [41] and the PM concentrations obtained in the present might have been affected by the extent of human activities (including the number of students visiting the office daily as well as the number of times the door have been opened) and the surrounding environment. Review of findings from various studies investigating particulate matter in ambient air at selected locations in Nigeria from $1985-2015$ showed that $\mathrm{PM}_{2.5}$ concentration ranged from $5-248 \mu \mathrm{g} / \mathrm{m}^{3}$ and $\mathrm{PM}_{10}$ concentration ranged from $18-926 \mu \mathrm{g} / \mathrm{m}^{3}$ [42]. According to Offor et al. [42], about $50 \%$ of the outdoor PM concentrations in Nigeria exceeded both the WHO (25 $\mu \mathrm{g} / \mathrm{m}^{3}, 50 \mu \mathrm{g} / \mathrm{m}^{3}$ ) and National Ambient Air Quality Standards (NAAQs) $\left(35 \mu \mathrm{g} / \mathrm{m}^{3}, 150 \mu \mathrm{g} / \mathrm{m}^{3}\right)$ guideline limits for $\mathrm{PM}_{2.5}$ and $\mathrm{PM}_{10}$ respectively. Based on the $\mathrm{PM}_{2.5} / \mathrm{PM}_{10}$ ratios (which fall below the WHO guideline, $0.5-0.8$ ) for the selected outdoor studies, it has been observed that the aerosols in Nigerian environment are mainly made up of more coarse particles and less fraction of fine particles. In a study, it has been observed that built-up areas of Nigerian cities are characterised with high levels of annual mean ambient airborne $\mathrm{PM}_{10}$ concentration of $>120 \mu \mathrm{g} / \mathrm{m}^{3}$ while rural areas had annual mean ambient $\mathrm{PM}_{10}$ values of $57.4 \mu \mathrm{g} / \mathrm{m}^{3}$ [43]. In a related study, Lee and Chang [44] investigated IAQ of five classrooms in Hong Kong and reported that the average respirable suspended particulate matter (RSPM) concentrations were higher than the Hong Kong air quality objective and the maximum indoor $\mathrm{PM}_{10}$ level which exceeded $1000 \mu \mathrm{g} / \mathrm{m}^{3}$.

There were no significant relationships among PM $\left(\mathrm{PM}_{1}, \mathrm{PM}_{2}, \mathrm{PM}_{5}, \mathrm{PM}_{10}\right)$ in occupied air-conditioned office during both rainy and dry seasons as shown in the correlation Table 3 and Table $5(P>0.050)$. However, correlation analysis indicated that $\mathrm{PM}_{1}, \mathrm{PM}_{2}$ and $\mathrm{PM}_{5}$ were significantly correlated at $P<0.01$ in unoccupied air-conditioned office during the rainy season and correlation coefficients were different (Table 4). In addition, correlation analysis also indicated that $\mathrm{PM}_{2}$ and $\mathrm{PM}_{5}$ were significantly correlated at $P<0.05$ in unoccupied air-conditioned office during the dry season (Table 6). In the present study, the highest coefficient was 0.735 for the relationship between $\mathrm{PM}_{5}$ and $\mathrm{PM}_{2}$ in unoccupied air-conditioned office during rainy season. The relationship of $\mathrm{PM}_{5}$ and $\mathrm{PM}_{2}$ in the study is very similar to the results reported by other researchers $[45,46]$. The results of correlation analysis indicated that fine particle $\left(\mathrm{PM}_{2}\right)$ are mainly particles from atmospheric and/or settling dust and also, $\mathrm{PM}_{2}$ accounted for most of $\mathrm{PM}_{5}$ levels in the unoccupied air-conditioned office. Although the BDL of $\mathrm{CO}$ and $\mathrm{CO}_{2}$ concentrations suggested that ventilation was sufficient in the airconditioned office during the sampling period, however, there is a need to provide a preventive cleaning strategy in order to further minimize health risks associated with PM pollution. However, relatively short time of the measurements and the small number of the monitored airconditioned offices potentially limited the ability to identify clear associations between the particle concentrations and other obtained indoor and outdoor air parameters.

Table 3. Correlation matrix among $\mathbf{P M}_{1}, \mathbf{P M}_{2}, \mathbf{P M}_{5}$, and $\mathbf{P M}_{10}$ concentrations in an occupied air-conditioned office during rainy season

\begin{tabular}{|c|c|c|c|c|c|}
\hline & Classification & PM1 & PM2 & PM5 & PM10 \\
\hline \multirow[t]{3}{*}{$\mathrm{PM}_{1}$} & Correlation Coefficient & 1 & 0.37 & 0.135 & -0.513 \\
\hline & $P$ Value & & 0.193 & 0.644 & 0.061 \\
\hline & Number of Samples & 14 & 14 & 14 & 14 \\
\hline \multirow[t]{3}{*}{$\mathrm{PM}_{2}$} & Correlation Coefficient & & 1 & 0.411 & 0.234 \\
\hline & $P$ Value & & & 0.145 & 0.421 \\
\hline & Number of Samples & & 14 & 14 & 14 \\
\hline \multirow[t]{3}{*}{$\mathrm{PM}_{5}$} & Correlation Coefficient & & & 1 & 0.094 \\
\hline & $P$ Value & & & & 0.749 \\
\hline & Number of Samples & & & 14 & 14 \\
\hline \multirow[t]{3}{*}{$\mathrm{PM}_{10}$} & Correlation Coefficient & & & & 1 \\
\hline & $P$ Value & & & & \\
\hline & Number of Samples & & & & 14 \\
\hline
\end{tabular}

Table 4. Correlation matrix among $\mathbf{P M}_{1}, \mathbf{P M}_{2}, \mathbf{P M}_{5}$, and $\mathbf{P M}_{10}$ concentrations in an unoccupied air-conditioned office during rainy season

\begin{tabular}{|c|c|c|c|c|c|}
\hline & Classification & PM1 & PM2 & PM5 & PM10 \\
\hline \multirow[t]{3}{*}{$\mathrm{PM}_{1}$} & Correlation Coefficient & 1 & 0.139 & 0.674 & -0.309 \\
\hline & $P$ Value & & 0.636 & 0.008 & 0.283 \\
\hline & Number of Samples & 14 & 14 & 14 & 14 \\
\hline \multirow[t]{3}{*}{$\mathrm{PM}_{2}$} & Correlation Coefficient & & 1 & 0.735 & -0.209 \\
\hline & $P$ Value & & & 0.003 & 0.472 \\
\hline & Number of Samples & & 14 & 14 & 14 \\
\hline \multirow[t]{3}{*}{$\mathrm{PM}_{5}$} & Correlation Coefficient & & & 1 & -0.343 \\
\hline & $P$ Value & & & & 0.23 \\
\hline & Number of Samples & & & 14 & 14 \\
\hline \multirow[t]{3}{*}{$\mathrm{PM}_{10}$} & Correlation Coefficient & & & & 1 \\
\hline & $P$ Value & & & & \\
\hline & Number of Samples & & & & 14 \\
\hline
\end{tabular}


Table 5. Correlation matrix among $\mathbf{P M}_{1}, \mathbf{P M}_{2}, \mathbf{P M}_{5}$, and $\mathbf{P M}_{10}$ concentrations in an occupied air-conditioned office during dry season

\begin{tabular}{|c|c|c|c|c|c|}
\hline & Classification & PM1 & PM2 & PM5 & PM10 \\
\hline \multirow[t]{3}{*}{$\mathrm{PM}_{1}$} & Correlation Coefficient & 1 & -0.373 & -0.068 & 0.086 \\
\hline & $P$ Value & & 0.189 & 0.818 & 0.771 \\
\hline & Number of Samples & 14 & 14 & 14 & 14 \\
\hline \multirow[t]{3}{*}{$\mathrm{PM}_{2}$} & Correlation Coefficient & & 1 & 0.384 & 0.081 \\
\hline & $P$ Value & & & 0.175 & 0.784 \\
\hline & Number of Samples & & 14 & 14 & 14 \\
\hline \multirow[t]{3}{*}{$\mathrm{PM}_{5}$} & Correlation Coefficient & & & 1 & 0.125 \\
\hline & $P$ Value & & & & 0.671 \\
\hline & Number of Samples & & & 14 & 14 \\
\hline \multirow[t]{3}{*}{$\mathrm{PM}_{10}$} & Correlation Coefficient & & & & 1 \\
\hline & $P$ Value & & & & \\
\hline & Number of Samples & & & & 14 \\
\hline
\end{tabular}

Table 6. Correlation matrix among $\mathrm{PM}_{1}, \mathrm{PM}_{2}, \mathrm{PM}_{5}$, and $\mathrm{PM}_{10}$ concentrations in an unoccupied air-conditioned office during dry season

\begin{tabular}{|c|c|c|c|c|c|}
\hline & Classification & PM1 & PM2 & PM5 & PM10 \\
\hline \multirow[t]{3}{*}{$\mathrm{PM}_{1}$} & Correlation Coefficient & 1 & 0.375 & 0.154 & -0.310 \\
\hline & $P$ Value & & 0.186 & 0.599 & 0.281 \\
\hline & Number of Samples & 14 & 14 & 14 & 14 \\
\hline \multirow[t]{3}{*}{$\mathrm{PM}_{2}$} & Correlation Coefficient & & 1 & 0.626 & 0.155 \\
\hline & $P$ Value & & & 0.017 & 0.597 \\
\hline & Number of Samples & & 14 & 14 & 14 \\
\hline \multirow[t]{3}{*}{$\mathrm{PM}_{5}$} & Correlation Coefficient & & & 1 & -0.228 \\
\hline & $P$ Value & & & & 0.434 \\
\hline & Number of Samples & & & 14 & 14 \\
\hline \multirow[t]{3}{*}{$\mathrm{PM}_{10}$} & Correlation Coefficient & & & & 1 \\
\hline & $P$ Value & & & & \\
\hline & Number of Samples & & & & 14 \\
\hline
\end{tabular}

\section{Conclusions}

The indoor air quality parameters $\left(\mathrm{PM}_{10}, \mathrm{PM}_{5}, \mathrm{PM}_{2}\right.$, $\mathrm{PM}_{1}, \mathrm{CO}, \mathrm{CO}_{2}$, relative humidity and temperature) were monitored in an occupied air-conditioned office and unoccupied air-conditioned office located in the Faculty of Natural and Applied Sciences Complex in Akwa Ibom State University Main Campus. The PM concentrations were significantly higher in the occupied air-conditioned office compared to those obtained in the unoccupied air-conditioned office. The higher PM concentration in the occupied air-conditioned office could be attributed to various human activities such as the opening of the door, printing, emissions from electronic devices as well as re-suspension of settled dust. Since there was no indoor sources for particle emission (such as smoking, cooking and vacuum cleaning), other human activities were probably the paramount factor that influenced the PM concentration. The results obtained in this study have shown strong seasonal variations of PM distributions and the occupied air-conditioned office had the highest concentration of PM compared to that in the unoccupied air-conditioned office. There is no evidence of a safe level of exposure or a threshold below which no adverse health effects may occur. Therefore, high concentrations of indoor PM levels obtained in the occupied air-conditioned office can adversely affect human health, performance and productivity of any staff. It is known that even at relatively low concentrations, the burden of air pollution on health is significant. Effective management of air quality aiming to achieve World Health Organization (WHO) Air Quality Guidelines is necessary to reduce human health risks to a minimum. The results obtained from this pilot study suggest the need for effective management of indoor air quality and strategy of using advanced current technologies to reduce ambient PM pollutants in our environment. The results obtained reveal important contributions towards understanding of indoor airborne PM distribution patterns and provide baseline data that can be used for potential identification of human health risks associated with particulate matter in the air-conditioned office in Akwa Ibom State University Nigeria.

\section{Acknowledgement}

The authors would like to acknowledge the technical support this project has received from the Coordinator, Research and Development (R\&D) Unit, Akwa Ibom State University - Nigeria.

\section{References}

[1] Wiseman, C. L. S., and F. Zereini, "Part I - Airborne Particulate Matter: Sources, Composition and Concentration," Urban Airborne Particulate Matter: Origin, Chemistry, Fate and Health Impacts, F. Zereini and C. L. S. Wiseman, eds., pp. 1-2, Berlin, Heidelberg: Springer Berlin Heidelberg, 2011.

[2] Pöschl, U., "Atmospheric Aerosols: Composition, Transformation, Climate and Health Effects," Angewandte Chemie International Edition, 44 (46). 7520-7540, 2005.

[3] Hinds, W. C., Aerosol Technology: Properties, Behavior, and Measurement of Airborne Particles: Wiley, 2012.

[4] Cohen, A. J., H. R. Anderson, B. Ostro, K. D. Pandey, M. Krzyzanowski, N. Künzli, K. Gutschmidt, C. Pope III, I. Romieu, and J. M. Samet, "Urban Air Pollution," Comparative Quantification of Health Risks: Global and Regional Burden of Disease Attributable to Selected Major Risk Factors, M. Ezzati, A. Lopez, A. Rodgers and C. J. L. Murray, eds., pp. 1353-1433, Geneva: World Health Organization, 2004.

[5] Celo, V., and E. Dabek-Zlotorzynska, "Concentration and Source Origin of Trace Metals in PM2.5 Collected at Selected Canadian Sites within the Canadian National Air Pollution Surveillance Program," Urban Airborne Particulate Matter: Origin, Chemistry, Fate and Health Impacts, F. Zereini and C. L. S. Wiseman, eds., pp. 19-38, Berlin, Heidelberg: Springer Berlin Heidelberg, 2011.

[6] Iavicoli, I., V. Leso, L. Fontana, and A. Bergamaschi, "Occupational Exposure to Urban Airborne Particulate Matter: A Review on Environmental Monitoring and Health Effects," Urban Airborne Particulate Matter: Origin, Chemistry, Fate and Health Impacts, F. Zereini and C. L. S. Wiseman, eds., pp. 501-525, Berlin, Heidelberg: Springer Berlin Heidelberg, 2011. 
[7] Jahn, H. J., A. Schneider, S. Breitner, R. Eißner, M. Wendisch, and A. Krämer, "Particulate matter pollution in the megacities of the Pearl River Delta, China - A systematic literature review and health risk assessment," International Journal of Hygiene and Environmental Health, 214 (4). 281-295, 2011.

[8] Calkovska, A., and E. Herting, "Exogenous surfactant in respiratory distress syndrome," Applied Technologies in Pulmonary Medicine, A. M. Esuinas, ed., pp. 205-209, Basel: Karger Publishers, 2010.

[9] Frew, A. J., S. R. Doffman, K. Hurt, and R. Buxton-homas, "Respiratory Disease," Kumar \& Clark Clinical Medicine, P. J. Kumar and M. L. Clark, eds., pp. 791-866, Saunders: Elsevier 2005.

[10] Kim, K.-H., E. Kabir, and S. Kabir, "A review on the human health impact of airborne particulate matter," Environment International, 74 136-143, 2015.

[11] Guaita, R., M. Pichiule, T. Mate, C. Linares, and J. Diaz, "Shortterm impact of particulate matter $(\operatorname{PM}(2.5))$ on respiratory mortality in Madrid," International Journal of Environmental Health Research, 21 (4). 260-274, 2011.

[12] Janssen, N. A. H., P. Fischer, M. Marra, C. Ameling, and F. R. Cassee, "Short-term effects of PM2.5, PM10 and PM2.5-10 on daily mortality in the Netherlands," Science of the Total Environment, 463-464 20-26, 2013.

[13] Halonen, J. I., T. Lanki, T. Yli-Tuomi, P. Tiittanen, M. Kulmala, and J. Pekkanen, "Particulate air pollution and acute cardiorespiratory hospital admissions and mortality among the elderly," Epidemiology, 20 (1). 143-153, 2009.

[14] Du, Y., X. Xu, M. Chu, Y. Guo, and J. Wang, “Air particulate matter and cardiovascular disease: the epidemiological, biomedical and clinical evidence," Journal of Thoracic Disease, 8 (1). E8-E19, 2016

[15] Brook, R. D., S. Rajagopalan, C. A. Pope, J. R. Brook, A. Bhatnagar, A. V. Diez-Roux, F. Holguin, Y. Hong, R. V. Luepker, and M. A. Mittleman, "Particulate matter air pollution and cardiovascular disease," Circulation, 121 (21). 2331-2378, 2010.

[16] Pope, C. A., and D. W. Dockery, "Health Effects of Fine Particulate Air Pollution: Lines that Connect," Journal of the Air \& Waste Management Association, 56 (6). 709-742, 2006.

[17] Davidson, C. I., R. F. Phalen, and P. A. Solomon, "Airborne Particulate Matter and Human Health: A Review," Aerosol Science and Technology, 39 (8). 737-749, 2005.

[18] Linares, C., and J. Diaz, "Short-term effect of concentrations of fine particulate matter on hospital admissions due to cardiovascular and respiratory causes among the over-75 age group in Madrid, Spain," Public Health, 124 (1). 28-36, 2010.

[19] Strak, M., G. Hoek, M. Steenhof, E. Kilinc, K. J. Godri, I. Gosens, I. S. Mudway, R. van Oerle, H. M. H. Spronk, F. R. Cassee, F. J. Kelly, R. M. Harrison, B. Brunekreef, E. Lebret, and N. A. H. Janssen, "Components of ambient air pollution affect thrombin generation in healthy humans: the RAPTES project," Occupational and Environmental Medicine, 70 (5). 332-340, 2013.

[20] Heudorf, U., V. Neitzert, and J. Spark, "Particulate matter and carbon dioxide in classrooms - The impact of cleaning and ventilation," International Journal of Hygiene and Environmental Health, 212 (1). 45-55, 2009.

[21] Graudenz, G. S., C. H. Oliveira, A. Tribess, C. Mendes, M. R. D. O. Latorre, and J. Kalil, "Association of air-conditioning with respiratory symptoms in office workers in tropical climate," Indoor Air, 15 (1). 62-66, 2005.

[22] Niu, J., "Some significant environmental issues in high-rise residential building design in urban areas," Energy and Buildings, 36 (12). 1259-1263, 2004.

[23] Chatoutsidou, S. E., J. Ondráček, O. Tesar, K. Tørseth, V. Ždímal, and M. Lazaridis, "Indoor/outdoor particulate matter number and mass concentration in modern offices," Building and Environment, 92 462-474, 2015.

[24] Sangiorgi, G., L. Ferrero, B. S. Ferrini, C. Lo Porto, M. G. Perrone, R. Zangrando, A. Gambaro, Z. Lazzati, and E. Bolzacchini, "Indoor airborne particle sources and semi-volatile partitioning effect of outdoor fine PM in offices," Atmospheric Environment, 65 205-214, 2013.

[25] Szigeti, T., Z. Kertész, C. Dunster, F. J. Kelly, G. Záray, and V. G. Mihucz, "Exposure to PM2.5 in modern office buildings through elemental characterization and oxidative potential," Atmospheric Environment, 94 44-52, 2014.
[26] Wolkoff, P., "Indoor air pollutants in office environments: Assessment of comfort, health, and performance," International Journal of Hygiene and Environmental Health, 216 (4). 371-394, 2013.

[27] Fromme, H., D. Twardella, S. Dietrich, D. Heitmann, R. Schierl, B. Liebl, and H. Rüden, "Particulate matter in the indoor air of classrooms-exploratory results from Munich and surrounding area," Atmospheric Environment, 41 (4). 854-866, 2007.

[28] Goyal, R., and M. Khare, "Indoor-outdoor concentrations of RSPM in classroom of a naturally ventilated school building near an urban traffic roadway," Atmospheric Environment, 43 (38). 6026-6038, 2009.

[29] Tippayawong, N., P. Khuntong, C. Nitatwichit, Y. Khunatorn, and C. Tantakitti, "Indoor/outdoor relationships of size-resolved particle concentrations in naturally ventilated school environments," Building and Environment, 44 (1). 188-197, 2009.

[30] Chithra, V. S., and S. M. Shiva Nagendra, "Indoor air quality investigations in a naturally ventilated school building located close to an urban roadway in Chennai, India," Building and Environment, 54 159-167, 2012.

[31] Thatcher, T. L., and D. W. Layton, "Deposition, resuspension, and penetration of particles within a residence," Atmospheric Environment, 29 (13). 1487-1497, 1995.

[32] Mendell, M. J., and G. A. Heath, "Do indoor pollutants and thermal conditions in schools influence student performance? A critical review of the literature," Indoor Air, 15 (1). 27-52, 2005.

[33] Shendell, D. G., R. Prill, W. J. Fisk, M. G. Apte, D. Blake, and D. Faulkner, "Associations between classroom $\mathrm{CO} 2$ concentrations and student attendance in Washington and Idaho," Indoor Air, 14 (5). 333-341, 2004.

[34] Seppänen, O. A., W. J. Fisk, and M. J. Mendell, “Association of Ventilation Rates and $\mathrm{CO} 2$ Concentrations with Health andOther Responses in Commercial and Institutional Buildings," Indoor Air, 9 (4). 226-252, 1999.

[35] Daisey, J. M., W. J. Angell, and M. G. Apte, "Indoor air quality, ventilation and health symptoms in schools: an analysis of existing information," Indoor Air, 13 (1). 53-64, 2003.

[36] Ramachandran, G., J. L. Adgate, S. Banerjee, T. R. Church, D. Jones, A. Fredrickson, and K. Sexton, "Indoor air quality in two urban elementary schools--measurements of airborne fungi, carpet allergens, CO2, temperature, and relative humidity," Journal of Occupational and Environmental Hygiene, 2 (11). 553-566, 2005.

[37] Godwin, C., and S. Batterman, "Indoor air quality in Michigan schools," Indoor Air, 17 (2). 109-121, 2007.

[38] Polednik, B., "Particulate matter and student exposure in school classrooms in Lublin, Poland," Environmental Research, 120. 134-139, 2013.

[39] Parker, J. L., R. R. Larson, E. Eskelson, E. M. Wood, and J. M. Veranth, "Particle size distribution and composition in a mechanically ventilated school building during air pollution episodes," Indoor Air, 18 (5). 386-393, 2008.

[40] WHO, Air Quality Guidelines: Global Update 2005: Particulate Matter, Ozone, Nitrogen dioxide, and Sulfur dioxide, Copenhagen, Denmark: World Health Organization, 2006

[41] Gusten, J., and O. Strindehag, "Experiences of measures taken to improve the air quality in schools," Air Infiltration Review, 16 (3). $5-8,1995$

[42] Offor, I. F., G. U. Adie, and G. R. E. E. Ana, "Review of Particulate Matter and Elemental Composition of Aerosols at Selected Locations in Nigeria from 1985 - 2015," Journal of Health and Pollution, 6 (10). 1-18, 2016.

[43] Efe, S. I., "Spatial distribution of particulate air pollution in Nigerian cities: Implications for human health," Journal of Environmental Health Research, 7 (2). 107-116, 2008.

[44] Lee, S. C., and M. Chang, "Indoor and outdoor air quality investigation at schools in Hong Kong," Chemosphere, 41 (1-2). 109-113, 2000.

[45] Chan, L. Y., W. L. Lau, S. C. Lee, and C. Y. Chan, "Commuter exposure to particulate matter in public transportation modes in Hong Kong," Atmospheric Environment, 36 (21). 3363-3373, 2002.

[46] Lam, G. C. K., D. Y. C. Leung, M. Niewiadomski, S. W. Pang, A. W. F. Lee, and P. K. K. Louie, "Street-level concentrations of nitrogen dioxide and suspended particulate matter in Hong Kong," Atmospheric Environment, 33 (1). 1-11, 1998. 